\title{
Pengaruh Gaya Kepemimpinan Terhadap Kedisiplinan Kerja Pegawai Dinas Pendidikan Dan Kebudayaan Kabupaten Penukal Abab Lematang llir
}

\author{
Hertanudin ${ }^{1}$, Yulia Pipin Sumantri ${ }^{2}$ \\ ${ }^{1}$ Sekolah Tinggi IImu Ekonomi Serasan Muara Enim, hertanudin24@gmail.com \\ ${ }^{2}$ Sekolah Tinggi IImu Ekonomi Serasan Muara Enim
}

\begin{abstract}
ABSTRAK
Tujuan dari penelitian ini adalah untuk mengetahui besar pengaruh gaya kepemimpinan terhadap kedisiplinan kerja pegawai Dinas Pendidikan dan Kebudayaan Kabupaten Penukal Abab Lematang llir. Teknik pengambilan sampel dengan cara random sampling. Dalam penelitian populasi di acak dan diambil sampel sebanyak 56 responden. Teknik pengumpulan data yang digunakan adalah kuesioner, observasi dan wawancara. Teknik analisis data menggunakan regresi linear sederhana, koefisien korelasi dan koefisien determinasi dengan metode kuantitatif deskriptif. Hasil penelitian menunjukkan bahwa persamaan garis linear $Y=19,59+0,47 X$ dan korelasi sebesar 0,495, hal ini menunjukkan adanya hubungan yang positif antara gaya kepemimpinan dan kedisiplinan kerja pegawai. Hasil penguji hipotesis diperoleh nilai thitung sebesar 4,821 dengan taraf signifikan 1,674 tersebut lebih besar dari 0,10 , yang berarti bahwa hipotesis dalam penelitian ini menerima $\mathrm{Ha}$ dan menolak Ho. Dan nilai koefisien determinasi 0,245 , hasil ini menunjukkan bahwa gaya kepemimpinan mampu menjelaskan perubahan yang terjadi pada kedisiplinan kerja pegawai sebesar $24,5 \%$. Terdapat hubungan yang positif dan erat antara variabel gaya kepemimpinan $(X)$ dengan variabel kedisiplinan kerja $(Y)$ yang terlihat dari hasil korelasi sebesar 0,495. Adanya pengaruh yang signifikan antara kedua variabel yang diteliti dan besarnya pengaruh gaya kepemimpinan dalam mempengaruhi kedisiplinan kerja adalah sebesar $24,5 \%$ dan sisanya sebesar $75,5 \%$ kedisiplinan kerja dipengaruhi oleh faktor lain yang tidak dibahas di dalam penelitian ini.
\end{abstract}

Kata Kunci: Gaya Kepemimpinan dan Kedisiplinan Kerja.

\section{A. PENDAHULUAN}

Kesuksesan atau kegagalan suatu organisasi ditentukan oleh banyak hal, salah satunya adalah kepemimpinan. Kepemimpinan dapat dikatakan sebagai cara dari seorang pemimpin dalam mengarahkan, mendorong dan mengatur seluruh unsur-unsur dalam kelompok atau organisasi untuk dapat mencapai tujuan. Salah satu kriteria pemimpin yang sukses adalah apabila pemimpin tersebut mampu menjadi pencipta dan pendorong bagi bawahannya dan dapat menciptakan suasana kerja yang dapat memacu peningkatan disiplin kerja pegawai.
Peran

kepemimpinan memberikan pengaruh yang cukup kuat dalam menciptakan disiplin kerja bagi para pegawainya. Kemampuan seorang pemimpin sebagai atasan dapat menentukan kualitas kerja pegawai, dimana dengan kepemimpinan yang tepat dapat membuat pegawai merasa nyaman dalam bekerja sehingga timbul semangat kerja dan rasa tanggung jawab atas pekerjaannya, maka dengan sendirinya akan timbul rasa kedisiplinan yang tinggi dari pegawainya.

Untuk mendapatkan sumber daya manusia yang diharapkan, organisasi dapat memberikan andil positif 
terhadap semua kegiatan organisasi guna untuk mencapai tujuannya. Setiap karyawan diharapkan memiliki motivasi kerja yang tinggi yang nantinya dapat meningkatkan disiplin kerja yang tinggi. Motivasi merupakan hal yang sangat penting untuk diperhatikan oleh organisasi bila mereka menginginkan setiap pegawainya dapat memberikan kontribusi yang positif pencapaian tujuan perusahaan, karena dengan motivasi seorang pegawai akan memiliki semangat yang tinggi dalam melaksanakan tugas yang dibebankan kepadanya. Tanpa motivasi seorang pegawai tidak mempunyai semangat untuk memenuhi tugas-tugas yang diberikan kepadanya dengan baik karena apa yang menjadi motivasinya dalam bekerja belum terpenuhi. Salah satu faktor penting dalam keberhasilan organisasi sangat bergantung dengan kepemimpinan. Jika seorang pemimpin mampu memberikan motivasi dan memberikan dorongan maka disiplin kerja akan tercipta dengan sendirinya.

Kedisiplinan merupakan salah satu fungsi manajemen sumber daya manusia yang terpenting, Kedisiplinan berhubungan dengan kemampuan pegawai menyelesaikan pekerjaan secara teratur. Keteraturan tersebut dapat dilihat dari perilaku setiap harinya. Bekerja dengan sungguhsungguh karena sadar dengan tugasnya merupakan amanah yang akan dipertanggung jawabkan dunia dan akhirat. Ini berarti kedisiplinan berkenaan dengan ketaatan seseorang yang secara sadar melaksanakan segala sesuatu yang telah ditetapkan dan adanya motivasi pada pegawai itu sendiri. Semakin baik tingkat disiplin seorang pegawai, maka akan semakin baik kinerja yang dapat dicapai pegawai.

Oleh karena itu peran kepemimpinan seorang pemimpin dalam memimpin organisasi sangat berpengaruh dalam tujuan organisasi. Pemimpin dalam memimpin organisasi harus mampu memberikan motivasi dan melihat tingkah laku pegawai sehingga disiplin akan tercipta dengan sendirinya. Sikap kepemimpinan sebaiknya sesuai dengan apa yang diinginkan oleh pegawai. Memberikan hak-hak pegawai sehingga pegawai menjalankan kewajiban-kewajiban di kantor. Mengingat pentingnya disiplin kerja pegawai, maka peran kepemimpinan sangat dibutuhkan sehingga para pegawai mampu memberikan kualitas kerja yang produktivitas yang tinggi agar tujuan yang diinginkan dapat tercapai.

Dinas Pendidikan dan
Kebudayaan Kabupaten Penukal Abab Lematang Ilir adalah kantor pelayanan masyarakat di bidang pendidikan dan kebudayaan yang beralamat di Jalan Arun Samping Koramil Kelurahan Talang Ubi Barat Kecamatan Talang Ubi. Kantor Dinas Pendidikan dan Kebudayaan mempunyai 3 sub bagian yaitu sub bagian umum dan kepegawaian, sub bagian keuangan dan sub bagian perencanaan serta mempunya 4 bidang yaitu bidang pendidikan dasar dan menengah, bidang sarana dan prasarana, bidang pendidikan luar sekolah dan bidang kebudayaan. Bagian-bagian ini memberikan laporan kepada kepala dinas, tak terkecuali pada subbagian umum dan kepegawaian. Dari hasil penelitian yang saya lakukan didapatkan informasi bahwa masih banyak pegawai yang tidak hadir pada saat apel pagi, senam kesegaran jasmani, terlambat masuk dan seringnya pulang kerja lebih dulu bahkan masih banyak pegawai yang tidak masuk kerja dengan alasan tertentu. Selain itu juga masih banyak pegawai yang tidak memakai pakaian 
seragam yang sesuai dengan peraturan yang telah ditetapkan.

Berdasarkan hasil wawancara dengan responden didapat informasi bahwa dengan kondisi yang ada, pimpinan belum melakukan teguran kepada para pegawai yang kurang disiplin sehingga mereka menjadi terbiasa dengan tingkah laku yang salah tersebut. Selain itu, pimpinan kurang memberikan motivasi kepada pegawai dalam bekerja. Pimpinan juga kurang memberikan arahan guna menciptakan suasana kerja yang lebih menyenangkan dan pimpinan belum memahami kelebihan dan keterbatasan yang dimiliki oleh pegawai serta belum memahami keinginan setiap pegawainya. Berikut tabel persentase rekapitulasi absensi pegawai dengan jumlah hari kerja efektif dalam setahun adalah 264 hari.

Tabel 1

Rekapitulasi Absensi Pegawai Dinas Pendidikan dan Kebudayaan

Kabupaten Penukal Abab Lematang Ilir

Tahun 2015 - September 2017

\begin{tabular}{|c|c|c|c|c|c|c|c|c|c|c|}
\hline \multirow{2}{*}{$\begin{array}{c}\text { N } \\
0\end{array}$} & \multirow{2}{*}{ Tahun } & $\begin{array}{c}\text { Jumlah } \\
\text { Pegawai }\end{array}$ & \multicolumn{2}{|c|}{ Izin } & \multicolumn{2}{|c|}{ Sakit } & \multicolumn{2}{|c|}{$\begin{array}{c}\text { Tanpa } \\
\text { Keterangan }\end{array}$} & \multicolumn{2}{|c|}{ Total } \\
\cline { 3 - 10 } & & & $\sum$ & $\%$ & $\sum$ & $\%$ & $\sum$ & $\%$ & $\sum$ & $\%$ \\
\hline 1 & 2013 & 48 & 21 & $\begin{array}{c}7,9 \\
5\end{array}$ & 5 & 1,89 & 11 & 4,17 & 37 & 14,02 \\
\hline 2 & 2014 & 93 & 89 & 33,71 & 54 & $\begin{array}{c}20,4 \\
5\end{array}$ & 25 & 9,47 & $\begin{array}{l}16 \\
8\end{array}$ & 63,64 \\
\hline 3 & 2015 & 146 & 57 & 21,59 & 48 & $\begin{array}{c}18,1 \\
8\end{array}$ & 72 & $\begin{array}{c}27,2 \\
7\end{array}$ & $\begin{array}{l}17 \\
7\end{array}$ & 67,05 \\
\hline 4 & 2016 & 125 & 74 & 28,03 & 51 & $\begin{array}{c}19,3 \\
2\end{array}$ & 36 & $\begin{array}{c}13,6 \\
4\end{array}$ & $\begin{array}{c}16 \\
1\end{array}$ & 60,98 \\
\hline
\end{tabular}

Sumber: Disdikbud Kabupaten PALI, Oktober 2017

Dari tabel 1 dapat diketahui bahwa dalam tiga tahun terakhir ini tingkat ketidakhadiran pegawai terus meningkat. Pada tahun 2015 tingkat ketidakhadiran pegawai hanya 37 hari dengan persentase $14,02 \%$. Pada tahun 2016 meningkat menjadi 168 hari dengan persentase 63,64\%. Bahkan pada tahun 2015 jumlah ketidakhadiran pegawai meningkat sampai 177 hari dengan persentase $67,05 \%$. Begitu pula pada tahun 2017 , baru sampai pada bulan september jumlah ketidakhadiran pegawai sudah mencapai 161 hari dengan persentase $60,98 \%$.

Hal ini menjadi catatan tersendiri mengapa terjadi peningkatan jumlah ketidakhadiran pegawai yang menggambarkan kedisiplinan kerja pegawai berkurang. Berdasarkan hasil kuisioner yang telah dilakukan oleh peneliti dengan cara membagikan kuesioner kepada 56 orang pegawai bahwa dari 56 responden 28 diantaranya merasa penerapan kedisiplinan di Kantor Dinas Pendidikan dan Kebudayaan Kabupaten Penukal Abab Lematang Ilir belum maksimal dan kebutuhan pegawai belum terpenuhi. Sedangkan pegawainyapun masih kurang memiliki kesadaran untuk menaati peraturan yang telah ditetapkan. Mereka juga belum memiliki rasa tanggung jawab terhadap pekerjaannya seperti pada bagian administrasi masih sering terlambat mengajukan berkas gaji 
pegawai, bendahara masih terlambat membuat laporan keuangan kantor, serta masing-masing bidang masih sering terlambat membuat laporan kegiatan yang telah dilaksanakan.

Di sisi lain, faktor-faktor pendukung pegawai untuk melakukan pekerjaan masih sangat terbatas seperti dalam satu ruangan hanya tersedia satu buah komputer, masih ada pegawai yang belum mendapatkan meja sehingga mereka susah untuk menyelesaikan pekerjaan dan belum tersedianya kendaraan operasional.

Berdasarkan uraian di atas, maka penulis tertarik untuk melakukan penelitian dengan judul "Pengaruh Gaya Kepemimpinan terhadap Kedisiplinan Kerja Pegawai Dinas Pendidikan dan Kebudayaan Kabupaten Penukal Abab Lematang Ilir".

\section{B. KAJIAN TEORI}

1. Pengertian Manajemen Sumber Daya Manusia

Menurut Abdurahmat Fathoni (2006:10): "Sumber Daya Manusia merupakan kekayaan yang paling penting yang dimiliki oleh suatu organisasi. Fenomena social pada masa kini dan masa depan dalam era globalisasi sangat menentukan keberhasilan perusahaan".

Menurut Sedermayanti (2014:13): "Manajemen Sumber Daya Manusia adalah Kebijakan dan praktik menentukan aspek manusia atau sumber daya manusia dalam posisi manajemen termasuk merekrut, menyaring, melatih, memberi penghargaan dan penilaian".

Menurut Veithzal Rivai dan Ella Jauvani Sagala Manajemen Sumber Daya Manusia Adalah kumpulan pengetahuan tentang bagaimana seharusnya mengelola sumber daya manusia. Faktor manusia merupakan masalah utama disetiap kegiatan yang ada di dalamnya. Organisasi merupakan kesatuan sosial yang dikoordinasikan secara sadar dengan sebuah batasan yang relatif dapat diidentifikasi, bekerja secara terus menerus untuk mencapai tujuan.

\section{Pengertian Kepemimpinan}

Menurut T. Hani Handoko (2012:294) mendefinisikan kepemimpinan sebagai suatu proses pengarahan dan pemberian pengaruh pada kegiatan-kegiatan dari sekelompok anggota yang saling berhubungan tugasnya.

Menurut Irham Fahmi (2012:15): "Kepemimpinan merupakan suatu ilmu yang mengkaji secara komprehensip tentang bagaimana mengarahkan, mempengaruhi dan mengawasi orang lain untuk mengerjakan tugas sesuai dengan perintah yang direncanakan".

T. Hani Handoko (2012:294) menyatakan bahwa Kepemimpinan merupakan kemampuan yang dipunyai seseorang untuk mempengaruhi orang-orang lain agar bekerja mencapai tujuan dan sasaran.

Menurut Malayu SP. Hasibuan (2013:170) menyatakan bahwa kepemimpinan adalah cara seorang pemimpin mempengaruhi perilaku bawahan, agar mau bekerjasama dan bekerja secara produktif untuk mencapai tujuan organisasi.

\section{Ciri-ciri Kepemimpinan}

Menurut Irham Fahmi (2012:18) untuk mewujudkan seseorang menjadi pemimpin yang ideal dibutuhkan syarat-syarat yang tergambar dalam ciri-ciri yang dimiliki. Adapun ciri-ciri untuk menjadi seorang pemimpin adalah: memiliki kompetensi yang sesuai dengan jamannya, artinya kompetensi yang dimilikinya sangat berguna untuk diterapkan pada saat itu dan kompetensi tersebut diakui oleh banyak pihak serta pakar khususnya. 
Memahami setiap permasalahan secara lebih dalam dibandingkan dengan orang lain serta mampu memberikan keputusan terhadap permasalahan tersebut. Mampu menerapkan konsep "The right men on the right place" secara tepat dan baik, artinya pemimpin adalah yang bisa melihat setiap potensi yang dimiliki oleh seseorang dan menempatkan potensi tersebut sesuai pada tempatnya.

\section{Sifat Kepemimpinan}

Menurut T. Hani Handoko (2012:297) sifat-sifat kepemimpinan adalah sebagai berikut:

a. Kemampuan dalam kedudukannya sebagai pengawas (Supervisory Ability) atau pelaksanaan fungsifungsi dasar manajemen, terutama pengarahan dan pengawasan pekerjaan orang lain.

b. Kebutuhan akan prestasi dalam pekerjaan, mencakup pencarian tanggung jawab dan keinginan sukses.

c. Kecerdasan, mencakup kebijakan, pemikiran kreatif dan daya pikir. Ketegasan atau kemampuan untuk membuat keputusan-keputusan dan memecahkan masalah-masalah dengan cakap dan tepat.

d. Kepercayaan diri atau pandangan terhadap dirinya sebagai kemampuan untuk menghadapi masalah.

e. Inisiatif atau kemampuan bertindak untuk tidak tergantung kepada orang lain, mengembangkan serangkaian kegiatan dan menemukan cara-cara baru atau inivatif.

\section{Gaya Kepemimpinan}

Malayu SP. Hasibuan (2013:172) menyatakan bahwa ada beberapa gaya kepemimpinan yaitu:

a. Kepemimpinan Otoriter
Kepemimpinan otoriter adalah jika kekuasaan atau wewenang sebagai besar mutlak tetap berada pada pimpinan. Pengambilan keputusan dan kebijaksanaan hanya ditetapkan sendiri oleh pemimpin, bawahan tidak diikutsertakan untuk memberikan saran, ide dan pertimbangan dalam proses pengambilan keputusan. Pada tipe ini, orientasi kepemimpinannya difokuskan hanya untuk peningkatan produktivitas kerja karyawan dengan kurang memperhatikan perasaan dan kesejahteraan bawahan.

b. Kepemimpinan Partisipatif

Yang dimaksud dengan kepemimpinan partisipatif adalah apabila dalam kepemimpinannya dilakukan dengan cara persuasive, menciptakan kerja sama yang serasi, menumbuhkan loyalitas dan partisipasi para bawahan. Pemimpin memotivasi bawahan agar merasa ikut memiliki perusahaan. Bawahan harus berpartisipasi memberikan saran, ide dan pertimbanganpertimbangan dalam proses pengambilan keputusan. Keputusan tetap dilakukan pimpinan dengan mempertimbangkan saran atau ide yang diberikan bawahannya.

c. Kepemimpinan Delegatif

Yang dimaksud dengan kepemimpinan delegatif apabila seorang pemimpin mendelegasikan wewenang kepada bawahan dengan agak lengkap. Dengan demikian, bawahan dapat mengambil keputusan dan kebijaksanaan dengan bebas atau leluasa dalam melaksanakan pekerjaannya. Di sini pimpinan menyerahkan 
tanggung jawab atas pelaksanaan pekerjaan kepada bawahan, dalam arti pimpinan menginginkan agar bawahan bisa mengendalikan diri mereka sendiri dalam menyelesaikan pekerjaan tersebut.

d. Kepemimpinan Situasional

Fokus pendekatan situasioal terhadap kepemimpinan terletak pada perilaku yang diobservasikan atau perilaku nyata yang terlihat, bukan pada kemauan atau potensi kepemimpinan yang dibawa sejak lahir. Penekanan pendekatan situasional adalah perilaku pemimpin dan anggota/ pengikut dalam kelompok dan situasi yang variatif.

\section{Fungsi Kepemimpinan}

Salah satu kriteria dalam menilai efektivitas kepemimpinan adalah kemampuan dalam mengambil keputusan. Kriteria yang penting untuk memperhatikan dalam menilai efektivitas kepemimpinan seseorang adalah kemampuan seorang pemimpin dalam menjalankan berbagai fungsi kepemimpinan, T. Hani Handokoo (2012:309) mengemukakan bahwa terdapat lima fungsi kepemimpinan yang hakiki, yaitu:

a. Fungsi Penentu Arah

Keterbatasan sumber daya organisasi mengharuskan pimpinan untuk mengelolanya dengan efektif, dengan kata lain arah yang hendak dicapai organisasi menuju tujuannya harus sedemikian rupa sehingga mengoptimalkan pemanfaatan dari segala sarana dan prasarana yang ada. Arah yang dimaksud tentang dalam strategi dan taktik yang disusun oleh pimpinan dalam organisasi.

b. Fungsi Juru Bicara
Mengharuskan seorang pemimpin untuk berperan sebagai penghubung antara organisasi perusahaan dengan pihak-pihak luar yang berkaitan dan berkepentingan. Peran ini sangat penting karena disadari bahwa tidak ada satupun organisasi yang hidup tanpa bantuan dari orang lain.

c. Fungsi Komunikator

Fungsi pemimpin sebagai komunikator lebih ditekankan pada kemampuannya untuk mengkomunikasikan sasaransasaran, strategi dan tindakan yang dilakukan oleh bawahan.

d. Fungsi Mediator

Semua konflik-konflik yang terjadi atau adanya perbedaan-perbedaan kepentingan dalam organisasi menurut kehadiran seorang pemimpin dalam menyelesaikan permasalahan yang ada.

e. Fungsi Integrator

Adanya pembagian tugas, sistem alokasi daya, dana dan tenaga serta diperlukannya spesialisasi pengetahuan dan keterampilan dapat menimbulkan sikap, perilaku dan tindakan oleh karenanya tidak boleh dibiarkan berlangsung terusmenerus. Dengan perkataan lain, diperlukan integrator terutama pada hirarki puncak organisasi. Integrator adalah pimpinan.

\section{Nilai-nilai Kepemimpinan}

Kepemimpinan tidak dapat terlepas dari nilai-nilai yang dimiliki oleh pemimpin seperti yang diungkapkan oleh Irham Fahmi (2012:23), yaitu:

a. Teoritik, yaitu nilai-nilai yang berhubungan dengan usaha untuk mencari kebenaran dan mencari pembenaran secara rasional.

b. Ekonomis, yaitu yang tertarik pada aspek-aspek kehidupan yang penuh 
keindahan, menikmati seperti peristiwa untuk kepentingan sendiri.

c. Sosial, menaruh belas kasihan terhadap orang lain, simpati, tidak mementingkan diri sendiri.

d. Politis, berorientasi pada kekuatan dan melihat kompetensi sebagai faktor yang sangat vital dalam kehidupannya.

e. Religius, selalu menghubungkan tiap aktivitas dengan kekuasaan sang pencipta.

\section{Pengertian Kedisiplinan Kerja}

Ada beberapa pengertian mengenai kedisiplinan kerja antara lain: Kedisiplinan kerja adalah kesadaran dan kesediaan seseorang menaati semua peraturan perusahaan dan norma-norma sosial yang berlaku (Malayu SP. Hasibuan, 2013: 193). Kedisiplinan kerja merupakan suatu alat yang digunakan para manajer untuk berkomunikasi dengan karyawan agar mereka bersedia untuk mengubah suatu perilaku serta sebagai suatu upaya untuk meningkatkan kesadaran dan kesediaan seseorang menaati semua peraturan perusahaan dan normanorma sosial yang berlaku (Veithzal Rivai dan Ella Jauvani Sagala, 2013:803).

Kedisiplinan kerja adalah suatu keadaan dimana semua tenaga yang berbeda di dalamnya baik organisasi pemerintahan maupun swasta harus mematuhi setiap tata tertib yang telah ditetapkan atau dibuat di dalam perusahaan baik secara tertulis maupun tidak tertulis dengan tujuan agar semua kegiatan berjalan dengan baik. Kedisiplinan kerja adalah sebagai sikap mental yang tercermin dalam perbuatan atau tingkah laku perorangan, kelompok atau masyarakat berupa ketaatan (obedience) terhadap peraturanperaturan atau ketentuan yang ditetapkan pemerintah atau etika, norma dan kaidah yang berlaku dalam masyarakat untuk tujuan tertentu (Sinungan, 2001: 145).

Disiplin juga dapat diartikan sebagai pengendalian diri agar tidak melakukan sesuatu yang bertentangan dengan filsafah dan moral pancasila. Dari pengertian di atas dapat menyimpulkan bahwa kedisiplinan mengacu pada pola tingkah laku dengan ciri-ciri sebagai berikut:

1. Adanya hasrat kuat untuk melaksanakan sepenuhnya apa yang sudah menjadi norma, etika dan kaidah yang berlaku dalam masyarakat.

2. Adanya perilaku yang dikendalikan.

3. Adanya ketaatan.

\section{Bentuk-bentuk Disiplin Kerja}

Menurut Veithzal Rivai dan Ella Jauvani Sagala. Bentuk-bentuk disiplin kerja adalah sebagai berikut:

1. Disiplin retributif adalah berusaha menghukum orang yang berbuat salah.

2. Disiplin korektif adalah berusaha membantu pegawai mengoreksi perilakunya yang tidak tepat.

3. Perspektif hak-hak individu adalah berusaha melindungi hak-hak dasar individu selama tindakan-tindakan disipliner.

4. Perspektif utilitarian adalah berfokus kepada pengguna disiplin yang hanya pada saat konsekuensikonsekuensi tindakan disiplin melebihi dampak negatifnya.

\section{Macam-macam Disiplin Kerja}

Menurut Mangkunegara (2011:129) ada dua macam bentuk disiplin kerja, yaitu:

1. Disiplin Preventif

Suatu upaya untuk menggerakkan pegawai mengikuti dan mematuhi pedoman kerja, aturan-aturan yang telah digariskan dari organisasi. 
Tujuan dasarnya adalah untuk menggerakkan pegawai agar disiplin diri dengan preventif, pegawai dapat memelihara dirinya terhadap peraturan-peraturan organisasi.

2. Disiplin Korektif

Suatu upaya untuk menggerakkan pegawai dalam menyatukan suatu peraturan dan mengarahkan untuk tetap mematuhi peraturan sesuai dengan pedoman yang berlaku pada organisasi. Pada disiplin korektif pegawai yang melanggar disiplin perlu diberikan sanksi sesuai dengan peraturan yang berlaku. Tujuan pemberian sanksi adalah untuk memperbaiki pegawai yang melanggar peraturan yang berlaku dan memberikan pelajaran kepada pelanggarnya.

\section{Hasil Penelitian Terdahulu}

Darti Astuti (2007), dengan judul Pengaruh Kepemimpinan Terhadap Kedisiplinan Kerja Karyawan. Penelitiannya dilakukan pada PT. Musi Hutan Persada Niru Sumatera Selatan. Hasil penelitian menunjukan hubungan antara kepemimpinan (X) terhadap kedisiplinan kerja (Y) sebesar 0,6994 dan memiliki pegaruh besar 69\%, Dari hasil penelitian maka dapat disimpulkan bahwa terdapat pengaruh yang positif dan signifikan antara kepemimpinan terhadap kedisiplinan kerja karyawan pada PT. Musi Hutan Persada Niru Sumatera Selatan.

Febriyanti (2014), dengan judul Peranan Kepemimpinan untuk Meningkatkan Disiplin Kerja pada Sub Bagian Operator. Penelitiannya dilakukan pada PT. Bangun Karya Pratama Lestari Tanjung Enim. Hasil penelitian menunjukkan bahwa kepemimpinan berpengaruh positif terhadap disiplin kerja, dari hasil perhitungan regresi linear sederhana diperoleh nilai korelasi antara $X$ dan $Y$ adalah sebesar 0,43. Dari hasil penelitian dapat ditarik kesimpulan bahwa terdapat pengaruh yang positif antara kepemimpinan terhadap displin kerja pada sub bagian operator di PT. Bangun Karya Pratama Lestari Tanjung Enim.

Aptrena Sarah (2015), dengan judul Pengaruh Gaya Kepemimpinan dan Motivasi Terhadap Disiplin Kerja. Penelitiannya dilakukan pada PT. Asuransi Umum Mega Kantor Pusat Bagian Administrasi. Hasil penelitian menunjukan hubungan antara gaya kepemimpinan (X1) terhadap disiplin kerja ( $Y$ ) sebesar 0,606 dan memiliki pegaruh besar $42,2 \%$, demikian pula dengan variabel motivasi kerja (X2) terhadap disiplin kerja $(Y)$ memiliki hubungan sebesar 0,671 dan memiliki pengaruh besar 51,8\%. Gaya kepemimpinan (X1) dan motivasi kerja (X2) terhadap disiplin kerja (Y) dilaksanakan secara simultan menunjukkan hubungan sebesar 0,735 dan memiliki pengaruh sebesar $54,0 \%$. Dari hasil penelitian maka dapat disimpulkan bahwa terdapat pengaruh yang signifikan antara gaya kepemimpinan dan motivasi kerja terhadap disiplin kerja karyawan pada PT. Asuransi Umum Bank Mega.

\section{Kerangka Pemikiran Teoritis}

Pegawai merupakan sumber daya yang mempunyai tempat terpenting dalam suatu organisasi baik pemerintahan maupun swasta. Diperlukan suatu sikap disiplin yang harus terus menerus dipelihara agar tercapai suatu hasil yang baik di lingkungan organisasi. Peran kepemimpinan memberikan pengaruh yang cukup kuat dalam menciptakan disiplin kerja bagi para pegawainya.

Menurut Hasibuan (2007:170) menyatakan bahwa kepemimpinan adalah cara seorang pemimpin mempengaruhi perilaku bawahan, agar mau bekerjasama dan bekerja secara 
produktif untuk mencapai tujuan organisasi. Jika kepemimpinan dalam suatu organisasi bagus, maka kedisiplinan kerja pegawainya akan bagus juga. Untuk memberikan gambaran yang jelas mengenai hubungan antara variabel yang akan diteliti maka digambarkan kerangka pemikiran sebagai berikut:

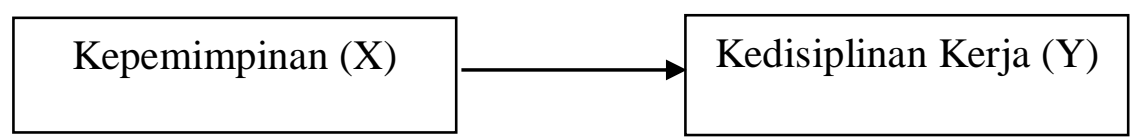

\section{Gambar 1 \\ Kerangka Pemikiran}

C. METODELOGI PENELITIAN

1. Jenis dan Sumber Data

Adapun jenis dan sumber data yang dikumpulkan penulis dalam penelitian ini adalah sebagai berikut :

\section{$>$ Data Primer}

Yaitu data dan informasi yang penulis peroleh langsung dari hasil wawancara dan observasi langsung dengan para karyawan dan pimpinan perusahaan bagaimana Gaya Kepemimpinan terhadap Kedisiplinan Kerja Pegawai Dinas Pendidikan dan Kebudayaan Kabupaten Penukal Abab Lematang llir

Data Sekunder

Yaitu data yang diperoleh dari Gaya Kepemimpinan terhadap Kedisiplinan Kerja Pegawai Dinas Pendidikan dan Kebudayaan Kabupaten Penukal Abab Lematang Ilir. Dengan membaca literatur yang ada hubungannya dengan objek penelitian ini.

\section{Teknik Pengumpulan Data}

a. Wawancara

Wawancara dengan Pimpinan dan Pegawai Dinas Pendidikan dan Kebudayaan Kabupaten Penukal Abab Lematang Ilir. Hal ini untuk mendapatkan data dan keterangan langsung dengan melakukan tanya jawab.

b. Observasi

Peneliti mengadakan pengamatan langsung terhadap objek yang diteliti. Data tersebut berupa kedisiplinan kerja karyawan dari beberapa unit kerja.

c. Kuesioner

Penyebaran kuesioner yang berisi daftar pertanyaan yang berhubungan dengan variabel yang diteliti. Dalam penelitian ini, kuesioner yang diberikan kepada responden bersifat tertutup, dimana responden hanya memilih alternatif jawaban yang tersedia pada kuesioner.

d. Studi Kepustakaan

Penelitian dapat mengumpulkan data dengan mempelajari masalah-masalah yang berhubungan dengan objek yang diteliti serta bersumber dari bukubuku pedoman yang disusun oleh ahli yang berhubungan dengan masalah yang diteliti.

\section{POPULASI DAN SAMPEL}

Populasi dalam penelitian ini adalah karyawan Pegawai Dinas Pendidikan dan Kebudayaan Kabupaten Penukal Abab Lematang Ilir yang berjumlah 125 orang. Teknik pengambilan sampel menggunakan 
random sampling, yaitu adalah teknik penentuan sampel yang diambil secara acak dari populasi. Dimana jumlah sampel yang diambil adalah 56 orang responden. Sugiyono (2012:122 123).

\section{E. HASIL DAN PEMBAHASAN}

Analisis data dalam penelitian ini menggunakan program Statistical Package For Sosial Sciencess (SPSS) Ver.22.0

\section{A. Uji Validitas}

Uji validitas digunakan untuk menguji sejauh mana ketepatan alat pengukur dapat mengungkapkan konsep gejala/ kejadian yang diukur. Item kuesioner dinyatakan valid apabila nilai $r$ hitung $>r$ tabel $(n-2)$. Pengujian validitas selengkapnya dapat dilihat pada tabel berikut ini.

Tabel 2

Hasil Uji Validitas Gaya Kepemimpinan

\begin{tabular}{|c|c|c|c|c|}
\hline No & Pernyataan Gaya Kepemimpinan & $r_{\text {hitung }}$ & $\mathbf{r}_{\text {tabel }}$ & Keterangan \\
\hline 1 & $\begin{array}{l}\text { Dalam bekerja pimpinan tidak selalu } \\
\text { ingin menang sendiri }\end{array}$ & 0,645 & 0,263 & Valid \\
\hline 2 & $\begin{array}{l}\text { Dalam bekerja pimpinan tidak selalu } \\
\text { ingin memaksakan kehendak }\end{array}$ & 0,536 & 0,263 & Valid \\
\hline 3 & $\begin{array}{l}\text { Dalam bekerja pimpinan tidak hanya } \\
\text { memerintah tapi juga mendengarkan } \\
\text { pendapat dari bawahan }\end{array}$ & 0,615 & 0,263 & Valid \\
\hline 4 & $\begin{array}{l}\text { Dalam bekerja pimpinan menerima } \\
\text { kritikan dan saran dari bawahan }\end{array}$ & 0,732 & 0,263 & Valid \\
\hline 5 & $\begin{array}{l}\text { Dalam berkomunikasi dengan } \\
\text { pegawai, pimpinan memberikan } \\
\text { respon timbal balik }\end{array}$ & 0,758 & 0,263 & Valid \\
\hline 6 & $\begin{array}{l}\text { Pimpinan selalu mengambil } \\
\text { keputusan berdasarkan mufakat }\end{array}$ & 0,610 & 0,263 & Valid \\
\hline 7 & $\begin{array}{l}\text { Pimpinan memiliki keyakinan tinggi } \\
\text { terhadap kompetensi pegawai dalam } \\
\text { melaksanakan tuqas bekeria }\end{array}$ & 0,581 & 0,263 & Valid \\
\hline 8 & $\begin{array}{l}\text { Pimpinan selalu memotivasi pegawai } \\
\text { dalam bekerja }\end{array}$ & 0,658 & 0,263 & Valid \\
\hline 9 & $\begin{array}{l}\text { Pimpinan melakukan pengendalian } \\
\text { emosi diri dalam melaksanakan tugas }\end{array}$ & 0,592 & 0,263 & Valid \\
\hline 10 & $\begin{array}{l}\text { Pimpinan memberikan arahan guna } \\
\text { menciptakan suasana kerja yang lebih } \\
\text { menyenangkan }\end{array}$ & 0,732 & 0,263 & Valid \\
\hline
\end{tabular}

Sumber: data primer, diolah, 2017

Pada tabel 2 terlihat bahwa korelasi antara masing-masing indikator terhadap total skor konstruk dari setiap variabel menunjukkan hasil yang signifikan dan menunjukkan bahwa $r$ hitung $>r$ tabel. Sehinggga dapat disimpulkan bahwa semua item pernyataan dinyatakan valid. 


\section{Tabel 3}

Hasil Uji Validitas Kedisiplinan Kerja

\begin{tabular}{|c|c|c|c|c|}
\hline No & Pernyataan Kedisiplinan Kerja & $r_{\text {hitung }}$ & $\mathbf{r}_{\text {tabel }}$ & Keterangan \\
\hline 1 & $\begin{array}{l}\text { Pegawai memiliki tujuan dan } \\
\text { kemampuan dalam bekerja Teladan }\end{array}$ & 0,605 & 0,263 & Valid \\
\hline 2 & $\begin{array}{l}\text { Pimpinan memberikan teladan yang } \\
\text { baik tentang kedisiplinan kerja }\end{array}$ & 0,702 & 0,263 & Valid \\
\hline 3 & $\begin{array}{l}\text { Instansi memberikan gaji pegawai } \\
\text { tepat waktu }\end{array}$ & 0,648 & 0,263 & Valid \\
\hline 4 & $\begin{array}{l}\text { Instansi memberikan kesejahteraan } \\
\text { kepada pegawai }\end{array}$ & 0,557 & 0,263 & Valid \\
\hline 5 & $\begin{array}{l}\text { Instansi melakukan pengawasan } \\
\text { melekat guna untuk meningkatkan } \\
\text { kedisiplinan pegawai }\end{array}$ & 0,570 & 0,263 & Valid \\
\hline 6 & $\begin{array}{l}\text { Pimpinan berani dan tegas pada } \\
\text { pegawai yang tidak disiplin sesuai } \\
\text { dengan sanksi yang telah ditetapkan }\end{array}$ & 0,686 & 0,263 & Valid \\
\hline 7 & $\begin{array}{l}\text { Pegawai mengikuti seluruh kegiatan } \\
\text { yang telah ditetapkan instansi }\end{array}$ & 0,522 & 0,263 & Valid \\
\hline 8 & $\begin{array}{l}\text { Pegawai menyelesaikan pekerjaan } \\
\text { sesuai dengan rencana dan tepat }\end{array}$ & 0,544 & 0,263 & Valid \\
\hline & waktu & 0,533 & 0,263 & Valid \\
\hline 9 & $\begin{array}{l}\text { Pegawal mengembangkan } \\
\text { kemampuan yang telah dimiliki }\end{array}$ & 0,716 & 0,263 & Valid \\
\hline 10 & $\begin{array}{l}\text { Pegawai memakai pakaian yang telah } \\
\text { ditetapkan oleh istansin }\end{array}$ & & & \\
\hline
\end{tabular}

Berdasarkan tabel 3 di atas terlihat bahwa korelasi antara masing-masing indikator terhadap total skor konstruk dari setiap variabel menunjukkan hasil yang signifikan dan menunjukkan bahwa $r$ hitung $>r$ tabel. Sehingga dapat disimpulkan bahwa semua item pernyataan dinyatakan valid.

Tabel 4

Kesimpulan Hasil Uji Validitas

\begin{tabular}{|l|l|c|c|c|}
\hline No & \multicolumn{1}{|c|}{ Variabel } & $\begin{array}{c}\text { Jumlah } \\
\text { Item }\end{array}$ & $\begin{array}{c}\text { Valid } \\
\text { Item }\end{array}$ & Keterangan \\
\hline 1 & Gaya Kepemimpinan $(\mathrm{X})$ & 10 & 10 & Semua item valid \\
\hline 2 & Kedisiplinan Kerja $(\mathrm{Y})$ & 10 & 10 & Semua item valid \\
\hline
\end{tabular}

Sumber: data penelitian, diolah, 2017

Dari tabel di atas terlihat bahwa korelasi antara masing-masing indikator terhadap total nilai skor konstruk dari setiap variabel menunjukkan hasil yang signifikan dan menunjukkan bahwa t hitung $>r$ tabel. Sehingga dapat disimpulkan bahwa semua item pernyataan dinyatakan valid.

\subsection{Uji Reliabilitas}

Uji reliabilitas digunakan untuk menguji sejauh mana keandalan suatu alat pengukur untuk dapat digunakan lagi untuk penelitian yang sama. 
Pengujian reliabilitas dalam penelitian ini adalah dengan menggunakan rumus Alpha. Hasil pengujian reliabilitas untuk masing-masing variabel dapat dilihat pada tabel berikut ini:

Tabel 5

Hasil Uji Reliabilitas

\begin{tabular}{|l|l|c|c|c|}
\hline No & \multicolumn{1}{|c|}{ Variabel } & $\begin{array}{c}\text { Cronbach } \\
\text { Alpha }\end{array}$ & $\begin{array}{c}\text { Standar } \\
\text { Reliabilitas }\end{array}$ & Keterangan \\
\hline 1 & Gaya Kepemimpinan & 0,82 & 0,60 & Reliabel \\
\hline 2 & Kedisiplinan Kerja & 0,80 & 0,60 & Reliabel \\
\hline
\end{tabular}

Sumber: Data primer, diolah, 2016

Hasil uji reliabilitas tersebut menunjukkan bahwa semua variabel mempunyai koefisien Alpha yang sangat baik yaitu untuk variabel gaya kepemimpinan sebesar 0,82 dan variabel kedisiplinan kerja sebesar 0,80 sehingga dapat dikatakan semua konsep pengukur masing-masing variabel dari kuesioner adalah reliabel dan untuk selanjutnya item-item pada masing-masing konsep variabel tersebut layak digunakan sebagai alat ukur.

\section{B. Uji Regresi Linier Sederhana}

Berdasarkan persamaan regresi di atas diperoleh nilai a sebesar 19,59 dan nilai b sebesar 0,47. Jadi persamaan garis regresinya adalah sebagai berikut:

$\mathrm{Y}=\mathrm{a}+\mathrm{bX}$

$Y=19,59+0,47 X$

Hal ini menunjukkan bahwa gaya kepemimpinan memiliki pengaruh positif terhadap kedisiplinan kerja pegawai yaitu 0,47 . Nilai koefisien regresi sebesar 0,47 menunjukkan bahwa apabila variabel $X$ (gaya kepemimpinan) sama dengan 0 (nol) maka nilai variabel $\mathrm{Y}$ (kedisiplinan kerja) sama dengan atau sebesar 0,47.

Dari analisis regresi ini maka dapat disimpulkan bahwa terdapat hubungan positif antara pengaruh gaya kepemimpinan terhadap kedisiplinan kerja pegawai. Jika gaya kepemimpinan ditingkatkan maka kedisiplinan kerja pegawai Dinas Pendidikan dan Kebudayaan Kabupaten Penukal Abab Lematang Ilir akan meningkat.

\section{Uji Koefisien Korelasi}

Untuk melihat keeratan hubungan antara variabel gaya kepemimpinan dalam meningkatkan kedisiplinan kerja pegawai dapat dilakukan dengan menggunakan analisis koefisien korelasi $(r)$.

1. Jika $r=0$ atau mendekati 0 , berarti tidak ada pengaruh antara pengaruh antara variabel kepemimpinan dan variabel kedisiplinan kerja.

2. Jika $r=1$ atau mendekati 1 , berarti ada pengaruh yang positif (sempurna) antara variabel kepemimpinan dan variabel kedisiplinan kerja.

3. Jika $r=-1$ atau mendekati -1 berarti pengaruh variabel kepemimpinan dan variabel kedisiplinan kerja berlawanan (negative sempurna).

Dari hasil perhitungan di atas dapat diketahui nilai koefisien korelasi (r) sebesar 0,495. Maka dapat disimpulkan terdapat pengaruh yang erat antara gaya kepemimpinan terhadap kedisiplinan kerja pegawai Dinas Pendidikan dan Kebudayaan Kabupaten Penukal Abab Lematang Ilir.. 


\section{Uji Hipotesis}

Untuk menguji signifikasi (taraf kepercayaan) pengaruh yaitu apakah pengaruh yang ditemukan itu berlaku untuk seluruh populasi yang berjumlah 125 orang, maka perlu diuji signifikasinya.

Uji t-hitung dengan rumus:

$\mathrm{t}_{\text {hitung }}=\frac{r \sqrt{n}-2}{\sqrt{1}-r^{2}}$

Jika $t_{\text {hitung }}>t_{\text {tabel }}$, maka Ho ditolak dan menerima $\mathrm{Ha}$, artinya ada pengaruh yang signifikan antara gaya kepemimpinan dan kedisiplinan kerja.

Jika $t_{\text {hitung }}<\mathrm{t}_{\text {tabel }}$, maka Ho diterima dan menolak $\mathrm{Ha}$, artinya tidak ada pengaruh yang signifikan antara kepemimpinan dan kedisiplinan kerja.

Harga $t$ tersebut selanjutnya dibandingkan dengan harga tabel. Untuk tingkat kesalahan $10 \%$ diuji 2 pihak dan $\mathrm{dk}=\mathrm{n}-2=56-2=54$, maka dapat diperoleh $\mathrm{t}_{\text {tabel }} 1,674$.

Dengan demikian dapat disimpulkan bahwa harga atau thitung 4,821 >ttabel 1,674, maka Ho ditolak dan menerima Ha. Berdasarkan perhitungan, maka ada pengaruh yang signifikan antara gaya kepemimpinan terhadap kedisiplinan kerja ( $\mathrm{Ha}$ diterima), dengan begitu koefisien tersebut dapat berlaku pada populasi dimana sampel tersebut diambil.

\section{E. Koefisien Determinasi}

Koefisien determinasi digunakan untuk menghitung seberapa besar kontribusi hubungan antara variabel independen dan variabel dependen.

$\mathrm{KD}=\mathrm{r}^{2} \times 100 \%$

$$
\begin{aligned}
& =0,495^{2} \times 100 \% \\
& =0,245
\end{aligned}
$$

Nilai koefisien koefisien determinasi $\left(R^{2}\right)=0,245$ yang berarti bahwa gaya kepemimpinan dapat menjelaskan pengaruh terhadap kedisiplinan kerja sebesar $24,5 \%$ dan sisanya $75,5 \%$ ditentukan oleh faktor lain yang tidak dibahas dalam penelitian ini

\section{F. KESIMPULAN DAN SARAN \\ 1) Kesimpulan}

Berdasarkan hasil analisis dan pembahasan yang telah dilakukan pada bab-bab sebelumnya, maka dapat disimpulkan sebagai berikut:

a. Terdapat hubungan yang positif dan erat antara variabel gaya kepemimpinan $(\mathrm{x}$ ) dengan variabel kedisiplinan kerja (y) yang terlihat dari hasil korelasi sebesar 0,495.

b. Adanya pengaruh yang signifikan antara kedua variabel yang diteliti.

c. Besarnya pengaruh gaya kepemimpinan dalam mempengaruhi kedisiplinan kerja adalah sebesar $24,5 \%$ dan sisanya sebesar 75,5\% kedisiplinan kerja dipengaruhi oleh faktor lain yang tidak dibahas di dalam penelitian ini.

\section{2) Saran}

Mengingat dominannya peranan pimpinan dalam membentuk karakter pegawai, maka pimpinan sebaiknya lebih sering lagi memberikan motivasi kepada pegawai baik motivasi positif maupun motivasi negatif.

a. Untuk meningkatkan kedisiplinan kerja pegawai, sebaiknya seorang pimpinan dapat melakukan kerja sama yang baik dengan bawahan atau pegawai, serta memberikan pengarahan maupun pengawasan yang bersifat otoriter agar pegawai dapat bekerja dengan baik, sehingga dapat membuat pegawai benar-benar melakukan pekerjaan dengan penuh semangat.

b. Agar instansi dapat berjalan sesuai yang diinginkan bersama, maka hendaknya sanksi 
hukuman lebih dipertegas lagi sehingga tidak ada lagi pegawai yang sering tidak masuk kerja tanpa alasan yang jelas.

\section{DAFTAR PUSTAKA}

Aptrena Sarah. 2015. Pengaruh Gaya Kepemimpinan dan Motivasi Terhadap Disiplin Kerja. Penelitiannya dilakukan pada PT. Asuransi Umum Mega Kantor Pusat Bagian Administrasi. Skripsi (tidak di publikasikan)

Darti Astuti. 2007. Pengaruh Kepemimpinan Terhadap Kedisiplinan Kerja Karyawan Pada PT. Musi Hutan Persada Niru Sumatera Selatan. Skripsi (tidak di publikasikan)

Febriyanti. 2014. Peranan Kepemimpinan untuk Meningkatkan Disiplin Kerja pada Sub Bagian Operator Pada PT. Bangun Karya Pratama Lestari Tanjung Enim. Skripsi (tidak di publikasikan)

Fathoni, Abdurrahmat. 2006. Manajemen Sumber Daya Manusia. Jakarta: PT. Renika Cipta.

Fahmi, Ilham. 2012. Manajemen Kepemimpinan Teori dan Aplikasi. Bandung. Alfabeta, CV
Handoko, T Hani. 2012. Manajemen.

Yogyakarta: BPFE.

Hasibuan, S.P Malayu, 2013. Manajemen Sumber Daya Manusia. Jakarta: PT. Bumi Aksara.

Mangkunegara, A.A Anwar Prabu. 2011. Manajemen Sumber Daya Manusia Perusahaan. Bandung: PT. Remaja Rosdakarya.

Oktariansyah, O. (2015). Pengaruh Kepemimpinan Dan Lingkungan Kerja Fisik Terhadap Motivasi Kerja Karyawan Cv. Sedulur Palembang. Jurnal Media Wahana Ekonomika, 9(2).

Veithzal, Rivai dan Jauvani Sagala, Ella, 2013. Manajamen Sumber Daya Manusia (Teori ke Praktek). Jakarta: PT. Raja Grafindo Persada.

Sedermanyanti. 2014. Manajemen Sumber Daya Manusia. Bandung: PT. Refika Aditama.

Sinungan, Muchdarsyah. 2001. Produktivitas Apa dan Bagaimana. Bandung. Bumi Aksara

Stoner, A.F. James. Et.al. 1996. Manajemen. Jilid II. Jakarta: PT. Prenhallindo.

Sugiyono, 2012. Metode Penelitian Bisnis. Bandung: Alfabeta. 